\title{
New cell line from adipopancreatic tissue of Atlantic herring Clupea harengus
}

\author{
S. Langner*, S. Rakers, P. Ciba, A. E. Petschnik, D. H. Rapoport, C. Kruse \\ Fraunhofer Institution for Marine Biotechnology, Fraunhofer Society, Paul-Ehrlich-Straße 1-3, 23562 Lübeck, Germany
}

\begin{abstract}
We report the isolation, cultivation, and cryopreservation of cells from adipopancreatic tissue of adult Atlantic herring Clupea harengus. The cell population was cultured for $>1 \mathrm{yr}$ and had a mean doubling time of $2 \mathrm{wk}$. Immunocytochemical analyses revealed that $>50 \%$ of cells contained glial fibrillary acidic protein and pan-cytokeratins. Vigilin, a well-conserved protein related to mRNA transport, was found in only $11 \%$ of cells. Alpha smooth-muscle actin and stage-specific embryonic antigen 1 were even less abundant $(<5 \%)$. Although little is known about tissue homeostasis and regeneration in adult $C$. harengus, the heterogeneity and long-term proliferation of the cell population described here suggest that it may contain stem cells or progenitor cells. Before the present study, there was only one $C$. harengus cell line available to researchers. The newly established cell line described in the present study represents an important addition to scientific investigation as well as aquaculture industries and toxicological/virological testing of herring populations.
\end{abstract}

KEY WORDS: Herring - Clupea harengus - Long-term fish cell culture - Fish cell line - Fish · Cryopreservation $\cdot$ Stem cells $\cdot$ Adipopancreatic tissue

Resale or republication not permitted without written consent of the publisher

\section{INTRODUCTION}

In modern aquaculture, it is a common problem that high population densities and inbreeding promote the spread of fish diseases. New cell lines and model systems are needed, especially for economically important fishes. Another challenge in aquaculture is to find adequate nutrition sources for carnivorous fishes. Currently, common feeding regimes use fish meal, which often leads to the absurd situation that more fish are fed than can be harvested (Naylor et al. 2000). Longterm proliferative cell cultures may offer a solution for both problems: they can be used to establish new cell lines that can be used to investigate diseases and drugs, and prospectively, may be a means to produce high-quality feed in large-scale cell reactors to reduce the use of fish meal. Also, highly unsaturated fatty acids, which are currently added to the diet for the fish, could be provided by fish cell culture, as proposed and demonstrated by Tocher \& Dick (1990).

The first fish cell lines were established in the 1960s to study viral diseases of fish (e.g. Gravell \& Mals- berger 1965, Wolf \& Vestergard Jorgensen 1970). More recently, fish cells have been used in biomedical research (Hightower \& Renfro 1988, Cole et al. 1997), and biotechnology (Bols 1991, Li et al. 1998, Galina et al. 2009), as well as in toxicology (Babich \& Borenfreund 1991, Schirmer et al. 1997, Segner 1998, Lee et al. 2009). Endocrine and genetic studies have been carried out using fish cell lines, e.g. to examine changes in the genome caused by viral diseases (Wise et al. 2009).

In the last few years, accumulation of expert knowledge about fish cell culture, along with advances in aquaculture, have led to the establishment of several new cell lines from economically important fishes (Bols 1991, Bejar et al. 1997, Segner 1998, Villena 2003, Ciba et al. 2008, Fan et al. 2010, Lakra et al. in press). Examples are caudal fin cells from gilt-head sea bream Sparus aurata (Bejar et al. 1997), neural stem cells from adult seabass Dicentrarchus labrax (Servili et al. 2009), muscle and fin cells of bluefin trevally Caranx melampygus (Zhao \& Lu 2006), gill cells from rainbow trout (Lee et al. 2009), and head kidney cells from Atlantic salmon Salmo salar (Dannevig et al. 1995). 
However, there is only one herring cell line described to date (Ganassin et al. 1999), and only one established cell line from fish pancreas (Pilz \& Plantikow 1991).

In the present study, we describe the first long-term growable cell line derived from the adipopancreatic tissue of Clupea harengus. It has been demonstrated previously by Kruse et al. $(2004,2006)$ and others (Seaberg et al. 2004, Seeberger et al. 2006, Gorjup et al. 2009, Rapoport et al. 2009) that proliferative cell populations can be obtained from exocrine pancreatic tissue with extraordinarily high yields. The preparation method used by Kruse et al. (2004) to isolate these cells has been subsequently expanded towards other species, such as Burchell's zebra Equus quagga burchellii, marine otter Lontra felina, and snow leopard Uncia uncia (cells of these 3 species were stored in the 'Alfred Brehm' German Cell Bank for Wild Animals, also called Cryo-Brehm) (Lermen et al. 2009, Ciba et al. 2010). From these studies, we concluded that exocrine glandular tissue might generally be a potent source to obtain long-term growable cell cultures, also from fishes.

In herring, the adipopancreatic tissue is located between the appendices pyloricae (Reichenbach-Klinke 1970); the pylorus itself is situated at the transition between stomach and intestinal tract (Reifel \& Travill 1978). The pylorus can be easily identified by virtue of its caeca, which appear as finger-like pouches (Buddington \& Diamond 1987, Domeneghini et al. 1999, Sanden et al. 2005, Marchetti et al. 2006). Adipopancreatic tissue was removed by dissection of the pylorus. Cells from these dissections were singularized by an enzymatic reaction and were used to establish the stable in vitro cultures described in the present study. We characterized the cells by morphology, proliferation rates and immunocytochemistry. We found the cells to be stable in the processes of long-term cultivation and cryopreservation.

\section{MATERIALS AND METHODS}

Tissue preparation and cell isolation. Three adult herring Clupea harengus from wildlife stock were obtained from the River Trave in Germany, from a local fisherman. Adipopancreatic tissue was isolated and transferred into digestion medium containing HEPESEagle medium ( $\mathrm{pH} 7.4$ ), 0.1 mM HEPES buffer ( $\mathrm{pH} 7.6$; Roth), $70 \%$ (v/v) modified Eagle medium (Invitrogen), $0.5 \%$ (v/v) Trasylol (Bayer), 1\% (w/v) bovine serum albumin (BSA; PAA Laboratories), $2.4 \mathrm{mM} \mathrm{CaCl}_{2}$, and collagenase (0.63 $\mathrm{U} \mathrm{mg}^{-1}$; Serva). The tissue was minced into small pieces (approx. $1 \mathrm{~mm}^{3}$ ) using surgical scissors and incubated for $20 \mathrm{~min}$ at $37^{\circ} \mathrm{C}$ with constant shaking (150 cycles $\left.\mathrm{min}^{-1}\right)$. Digestion medium together with fat tissue was removed, and after rinsing with isolation medium (digestion medium without collagenase), the remaining tissue fragments were dissociated by up- and down-suction (shear forces) through glass pipettes (Roth) with progressively more restrictive openings $(20 \mathrm{ml}, 10 \mathrm{ml}, 5 \mathrm{ml})$, resulting in a single cell suspension. Afterwards, the cells were centrifuged for $5 \mathrm{~min}$ at $20^{\circ} \mathrm{C}$ and $115 \times \mathrm{g}$, then resuspended and seeded in culture medium (Dulbecco's modified Eagle medium [DMEM]; Gibco ${ }^{\circledR}$, Invitrogen) supplemented with $20 \%$ fetal calf serum (FCS; PAA Laboratories), $100 \mathrm{U} \mathrm{ml}^{-1}$ penicillin (Biochrom), and $0.1 \mathrm{mg} \mathrm{ml}^{-1}$ streptomycin (Biochrom).

Cell culture. Cells were cultured in $25 \mathrm{~cm}^{3}$ culture flasks (TPP) in standard culture medium at $20^{\circ} \mathrm{C}$ and $2 \%$ $\mathrm{CO}_{2}$. The medium was changed $2 \mathrm{~d}$ after seeding, and subsequently on every 4 th day. The cells were subcultured ('passaged') in a 1:1 ratio as soon as confluency was reached using trypsin $\left(0.5 \mathrm{mg} \mathrm{ml}^{-1}\right)$ and EDTA $\left(0.22 \mathrm{mg} \mathrm{ml}^{-1}\right)$ (PAA Laboratories). Total cell number and dead cells were counted using the NucleoCounter ${ }^{\circledR}$ $\mathrm{NC}-100+$ (Chemometec). If needed for seeding, frozen cells were thawed rapidly in $20^{\circ} \mathrm{C}$ culture medium, spun down for 5 min at $115 \times g$, and resuspended and seeded in culture medium. For immunocytochemical studies, cells were transferred onto 2-well chamber slides (BD Biosciences) $3 \mathrm{~d}$ before examination.

Cell proliferation assay. The herring cells were seeded in $100 \mu \mathrm{l}$ of $20 \%$ culture medium at densities of $2 \times 10^{4}, 1 \times 10^{4}, 5 \times 10^{3}$, and $2.5 \times 10^{3}$ cells $0.31 \mathrm{~cm}^{-2}$ into a 96-well microtiter plate with electrodes. These electrode plates are part of a commercially available impedance-based online cell-monitoring system (Xcelligence, E-Plate-96; Roche). In this system, cell status is represented by the relative change in electrical impedance. The arbitrary unit of this system is called the cell index $(C I)$. It is defined as $C I=Z_{i}-Z_{0}$, where $Z_{i}$ is the cell-electrode impedance of the well when it contains cells at an individual time point during the experiment, and $Z_{0}$ is the background impedance at the start of the experiment of wells containing medium only (Roche Applied Science 2008). $Z_{\mathrm{i}}$ is a complex parameter, the value of which depends simultaneously on cell number, cell size, and confluency of the cell culture. In this experiment, impedance was measured over a period of 4 to $6 \mathrm{~d}$ to monitor cell proliferation. At the beginning of the experiment, 1 measurement was taken as blank. After $30 \mathrm{~min}$, the attachment, spreading, and proliferation of the cells were monitored every 15 min with RTCA 1.2.0.0909 software (Roche). Cells were cultured at 16 and $20^{\circ} \mathrm{C}\left(2 \% \mathrm{CO}_{2}\right)$ to investigate the influence of temperature on cell growth.

Cryopreservation. Trypsinated cells were suspended in $4^{\circ} \mathrm{C}$ freezing medium consisting of $90 \% \mathrm{FCS}$ and $10 \%$ dimethyl sulfoxide (DMSO; Roth) and transferred into cryovials. The vials were immediately 
conveyed into a precooled isopropanol-freezing box (Nalgene), which, in a $-80^{\circ} \mathrm{C}$ freezer, achieves a cooling rate of $1^{\circ} \mathrm{C} \mathrm{min}{ }^{-1}$. After 1 night of cooling/storage at $-80^{\circ} \mathrm{C}$, the vials were transferred into the liquid nitrogen atmosphere at the Cryo-Brehm, a cell bank for cryopreservation and archiving of proliferative cells obtained from wild animals.

Immunocytochemistry. For immunostaining, cells of Passage 7 cultivated on chamber slides were rinsed with phosphate-buffered saline (PBS), fixed with a mixture of methanol and acetone (7:3) containing $1 \mu \mathrm{g} \mathrm{ml}^{-1}$ DAPI stain (Roche) for $5 \mathrm{~min}$ at room temperature, and washed 3 times in PBS. After incubation with $1.7 \%$ normal goat serum at room temperature for $20 \mathrm{~min}$, the samples were incubated with interspecies cross-reactive primary antibodies in a humid chamber for $1 \mathrm{~h}$ at $37^{\circ} \mathrm{C}$. These antibodies are directed against: pan-cytokeratins containing CK1, CK4, CK5, CK6, CK8, CK10, CK13, CK18, and CK19 (monoclonal mouse, 1:100; catalog number [CN]: C2562; SigmaAldrich $\left.{ }^{\circledR}\right)$, which stain the epithelial filamentous structures in the cells; vigilin, a marker which shows the transcriptional level of the cells (polyclonal anti-vigilin antiserum FPIII, rabbit, 1:200; Kruse et al. 1996); nestin, a stem cell marker as well as a marker for neuroepithelial cells (rabbit polyclonal, 1:250; CN: ab5968; Abcam ${ }^{\circledR}$ ); glial fibrillary acidic protein (GFAP), a marker for ectodermal structures (rabbit polyclonal, 1:100; CN: Z0334; Dako); alpha smooth-muscle actin (alpha-SMA), a marker for mesodermal structures (mouse monoclonal, 1:100; CN: M0851; Dako); Ki-67, a proliferation marker located in the nucleus (rabbit polyclonal, 1:500, CN: ab 15580; Abcam $\left.{ }^{\circledR}\right)$; octamerbinding transcription factor 4 (Oct-4), a stem cell marker also located in the nucleus (monoclonal mouse, 1:50, CN: MAB 4305; Chemicon); stage-specific embryonic antigen 1 (SSEA-1), a marker for stem cells and located at the cell surface (monoclonal mouse, 1:50, CN: MAB 4301; Chemicon); and MF20, a banded muscle marker (mouse monoclonal, 1:50; CN: MF20; DSHB). Nestin, GFAP, alpha-SMA, and MF20 are all filamentous structures. After rinsing 3 times with PBS, the slides were incubated with secondary antibodies in a humid chamber for $1 \mathrm{~h}$ at $37^{\circ} \mathrm{C}$. The following secondary antibodies were used: cyanine-3 (Cy3)-labeled anti-mouse IgG (1:400; Dianova) and fluorescein isothiocyanate (FITC)-labeled anti-rabbit IgG (1:200; Dianova). Slides were washed 3 times in PBS, covered in Vectashield ${ }^{\circledR}$ mounting medium (Vector Laboratories), and analyzed under a fluorescence microscope (Axioscope 2 ; Zeiss). The images were captured using an AxioCam MRc5 (Zeiss) and processed with AxioVision40 software (version 4.7.1). Negative control was carried out with the secondary antibody alone. As a positive control, goat submandibular gland cells, human parotid gland cells, Schwann cells isolated from rat nervus ischiadicus, and oocyte-like cells (rat) were used. For quantitative analyses, 3 representative micrographs each were analyzed by determining the fraction of marker that was positive out of 100 to 200 cells. This image analysis was carried out 3 times for each marker protein and the average of the 3 values was calculated.

Database-assisted sequence analysis. With the basic local alignment search tool (BLAST, UniProt Knowledgebase, www.expasy.ch) the sequences of Danio rerio, Salmo salar, Oryzias latipes and Carassius auratus were compared to those of human and mouse to determine the binding specificity of the antibodies used for immuncytochemistry. The 4 fish species were chosen because no sequences of Clupea harengus were available in the BLAST program.

\section{RESULTS}

\section{Isolation and cultivation}

The isolated primary cells attached to the bottom of the cell culture flask but proliferated initially very slowly. Only 1 cell line reached confluency 6 wk after preparation. The cells were split, and after 3 passages, the cell proliferation rate had accelerated to a doubling time of roughly $2 \mathrm{wk}$ and the cells grew continuously in standard DMEM supplemented with 20\% FCS. Trypsinization of the cells for passaging did not cause a significant loss of viability (roughly $10 \%$ dead cells). Fig. 1 displays the morphology of the cell population under bright field microscopy. In Fig. 1a, cells of Passage 0 are shown. Polygonal-shaped cells were mingled with large, rather round cells containing filamentous structures (Fig. 1d). In Passage 2 (Fig. 1b), lipid inclusions were observed in some of the cells (Fig. 1c). The quantity of cells with lipid inclusions decreased during cultivation (Fig. 1d).

\section{Cell proliferation assay}

At $20^{\circ} \mathrm{C}$, high seeding densities $\left(2 \times 10^{4}\right.$ and $10 \times 10^{3}$ $0.31 \mathrm{~cm}^{-2}$ ) led to growth inhibition; after attachment, the CI basically remained constant (Fig. 2a). Cell proliferation was observed at lower seeding densities; after $96 \mathrm{~h}$, the CI reached a plateau. This plateau was almost 2 times higher for the $5 \times 10^{3}$ cells $0.31 \mathrm{~cm}^{-2}$ seeding density than for $2.5 \times 10^{3}$ cells $0.31 \mathrm{~cm}^{-2}$. At $16^{\circ} \mathrm{C}$, proliferation seemed to stagnate. Regardless of the seeding density, a plateau phase was reached quickly (after $24 \mathrm{~h}$ ) and no changes in CI occurred thereafter (Fig. 2b). 

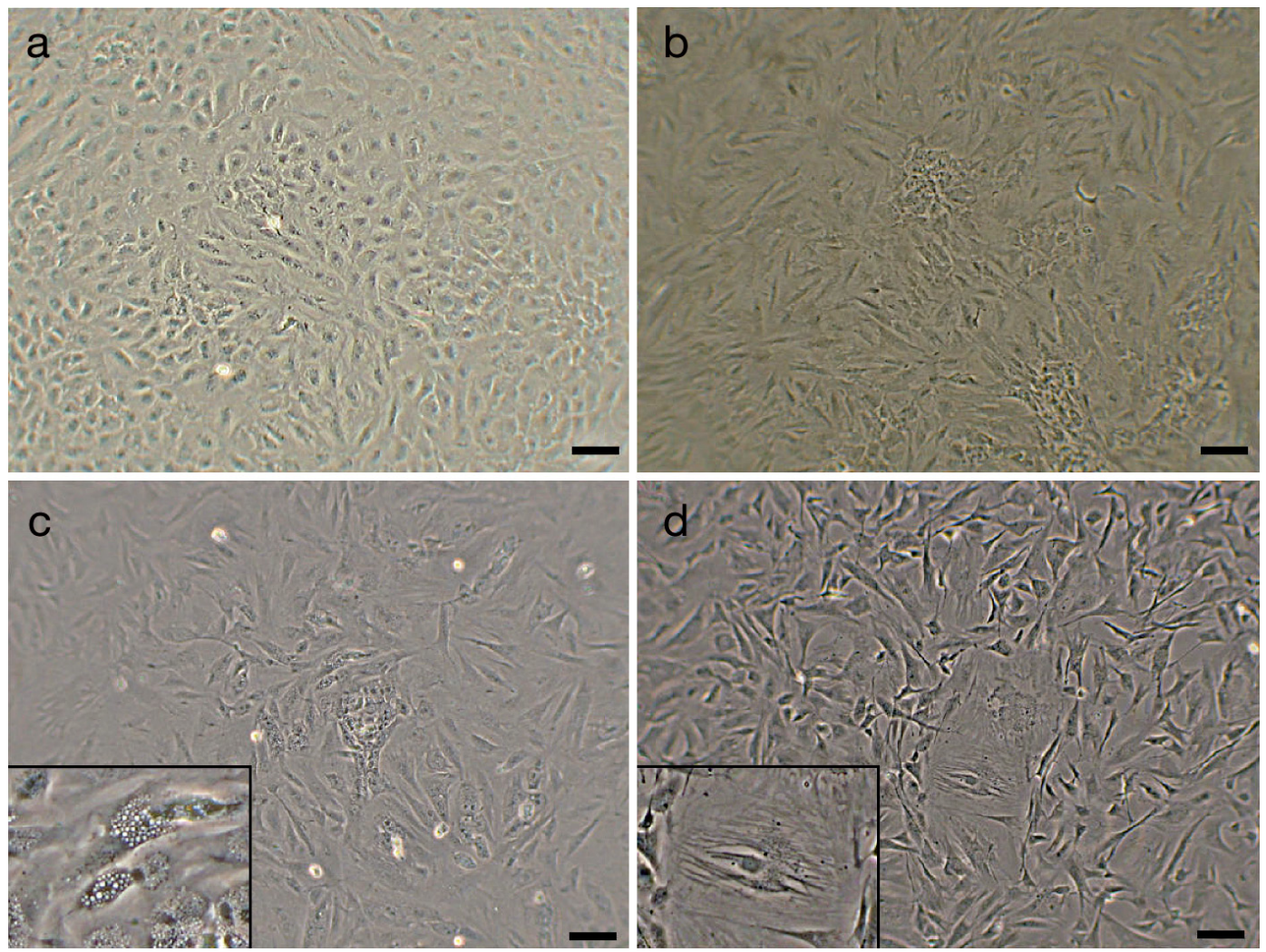

Fig. 1. Clupea harengus. Morphology of subcultured cells from adipopancreatic tissue. (a) Primary cell population in Passage 0. $(b, c)$ Cells of Passage 2. The inset in (c) depicts lipid inclusions; the number of cells with lipid inclusions decreased in the higher passages. (d) Cell population in Passage 7; from this passage on, morphological appearance remained basically unaltered. The inset in (d) displays the typical filamentous structures of the final cell population. Scale bars $=100 \mu \mathrm{m}$

\section{Cryopreservation}

Freezing and thawing did not lead to a significant loss in cell viability: $85 \%$ of the frozen cells were viable after thawing. Three days after thawing and re-seeding, cells started to proliferate again.

\section{Immunocytochemistry}

The glial stem cell marker GFAP showed an interaction in $54 \%$ of cells (Fig. 3e). The RNA-binding protein vigilin was present in the cytoplasma in $11 \%$ of cells (Fig. 3c). Interaction of the alpha-SMA antibody with the typical filamentous structures was found in only a few cells (Fig. 3a). Clupea harengus cells were $78 \%$ pan-cytokeratin-positive (Fig. 3g), while only $3 \%$ of cells were SSEA-1-positive (Fig. 3i). The nestin antibody showed no positive interaction (not shown). Also, MF20 (a marker for sarcomeric myosin), the transcription factor Oct-4, and the proliferation marker Ki-67 were not detected (not shown). The fraction of markerpositive cells is shown in Fig. 4.

\section{Database-assisted sequence analysis}

Analysis using the basic local alignment search tool (BLAST) revealed that GFAP in Danio rerio, alphaSMA in D. rerio, Salmo salar, and Oryzias latipes, Ki-67 in $S$. salar, and vigilin in D. rerio and $S$. salar have a sequence similarity with the human/murine sequence of $\geq 60 \%$. For nestin, only a $30 \%$ homology with a nestin fragment from Carassius auratus was determined; sequences of nestin in the other 3 fish species were not found.

\section{DISCUSSION}

The present study describes the first successful attempt to establish a long-term cell culture from adipopancreatic tissue of Atlantic herring. This cell population was cultivated for $>1 \mathrm{yr}$. The cells were passaged 15 times (roughly 30 cell doublings) with a doubling time of $2 \mathrm{wk}$.

Initially, the cells proliferated significantly slowly, indicating a transition period during which the cells 

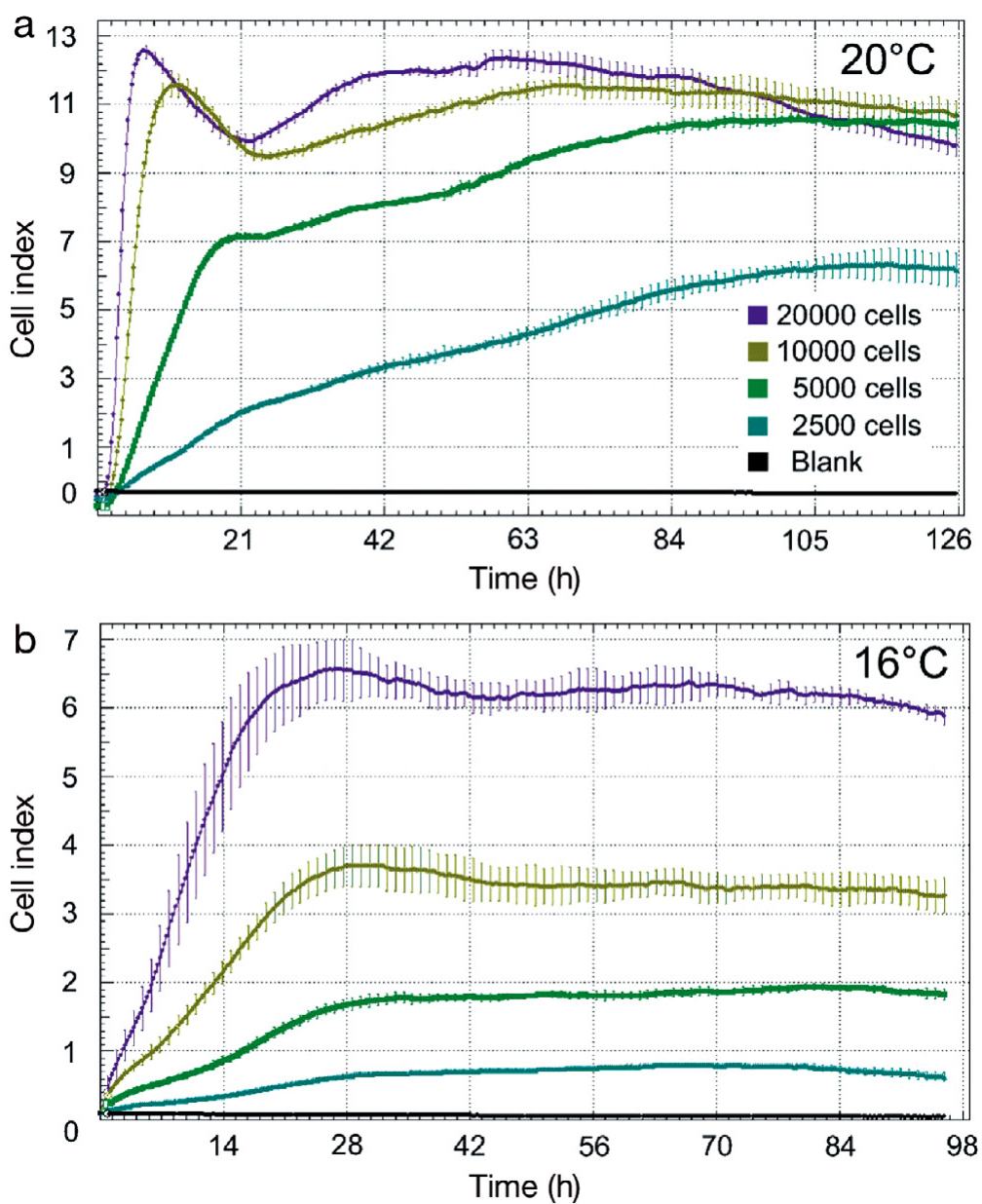

Fig. 2. Clupea harengus. Cell proliferation assay at 2 different temperatures. Vertical lines are data $\pm \mathrm{SD}$. (a) At $20^{\circ} \mathrm{C}$, the seeding densities of $2 \times 10^{4}$ and $1 \times 10^{4}$ cells $0.31 \mathrm{~cm}^{-2}$ revealed an initial decline of the cell index (CI). In contrast, densities of $5 \times 10^{3}$ and $2.5 \times 10^{3}$ cells $0.31 \mathrm{~cm}^{-2}$ showed a continuous proliferation after adhesion. A seeding density of $5 \times 10^{3}$ cells $0.31 \mathrm{~cm}^{-2}$ (roughly $1.6 \times 10^{4} \mathrm{cells} \mathrm{cm}^{-2}$ ) yielded the best proliferation rates. (b) At $16^{\circ} \mathrm{C}$, no stable proliferation could be attained at any seeding density. Instead, a steady state was reached after $48 \mathrm{~h}$

adapted to their new environment. Also, it is evident that in vitro culturing selects for the fastest-growing cell population, which should accumulate over time. These reasons might explain the initial increase in the proliferation rates.

The fact that the cells proliferate over such long time periods suggests that the in vitro cell population does not contain only somatic cells. In mammals, terminally differentiated somatic cells stop dividing after a limited number of population doublings and undergo apoptosis (Holt et al. 1997, Tang et al. 2001, Ohtani et al. 2009). We consider it to be unlikely that oncogenic alterations might account for the observed cell type. The herring cells described in the present study displayed no morphological signs of nuclear aberrations such as polynucleated cells or large nuclei. Moreover, in contrast to most tumor cell lines, the herring cells did not grow in multiple layers and did slow their proliferation notably when reaching confluency (see proliferation curves in Fig. 2).

Taking into account these considerations, we hypothesize that the cell population described here contains progenitor or adult stem cells. Not only are adult stem cells known to be proliferative over long time periods while keeping their ability for contact inhibition (Pittenger et al. 1999, Poulsom et al. 2002), but exocrine pancreatic tissue is a very efficient source for multi- and pluripotent adult stem cells in various species (Kruse et al. 2006, Lermen et al. 2009). In fact, the propensity of exocrine pancreatic tissue to yield high amounts of stem- or progenitor cells has been utilized to establish the CryoBrehm cell bank for viable cells of a large variety of endangered vertebrates (Lermen et al. 2009, Ciba et al. 2010).

Compared with mammals, little is known about tissue homeostasis and regeneration in adult Clupea harengus. It seems, however, plausible that adult stem cells, regardless of the specific physiological process they are involved in, should continuously give rise to several different cell types. Therefore, we analyzed the heterogeneity of protein expression within the cell population. Using immunocytochemical stainings, we tested for the expression of known stem-cell-specific marker proteins (Oct-4, Nestin, and SSEA-1), as well as of particular differentiation markers (alpha-SMA, GFAP, MF20, pan-cytokeratin, Ki-67, and vigilin) in different passages.

Unfortunately, there are virtually no antibodies available that are directed specifically against protein epitopes from Atlantic herring. Most available antibodies bind to murine and human proteins. Therefore, we compared the sequences of commonly used human and murine marker proteins (Oct-4, GFAP, alpha-SMA, nestin, and vigilin) to the homologous proteins from other fish species such as Danio rerio, Salmo salar, Oryzias latipes, and Oncorhynchus mykiss using UniProt Knowledgebase (www.expasy.ch). The results indicate that GFAP, alpha-SMA, Ki-67, and vigilin have a good chance of being detected using anti-human/anti-murine antibodies (>60\% homology).

Another important criterion to assess the specificity of a particular antibody is its spatial binding pattern within the cell. In particular, fibrillary proteins, such as GFAP and cytokeratins, display rather specific structures. Therefore, we infer from the data in Fig. 3 that 

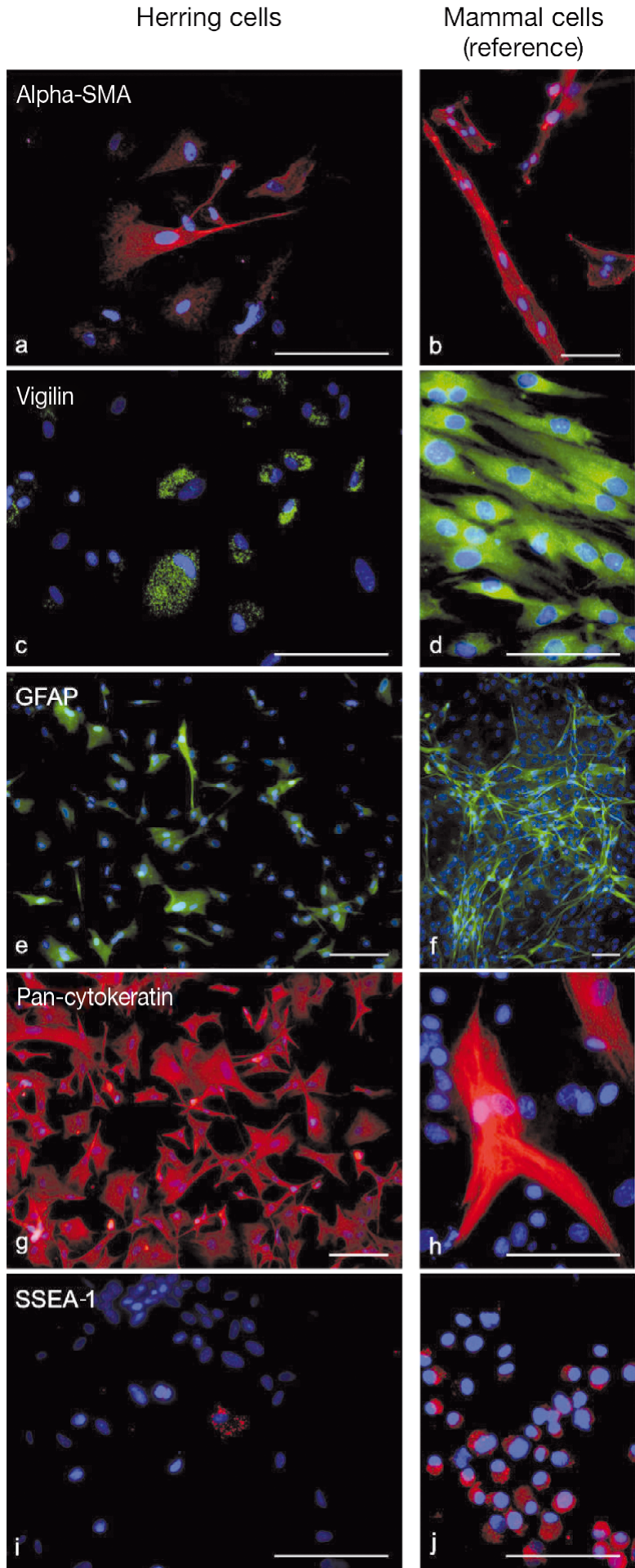

Fig. 3. Clupea harengus. Immunocytochemical analyses of $(a, c, e, g, i)$ isolated herring cells from adipopancreatic tissue and $(b, d, f, h, j)$ mammalian cells as a positive control. Fluorescence microscopy following incubation with antibodies against $(a, b)$ alpha smooth-muscle actin (alpha-SMA); $(\mathrm{c}, \mathrm{d})$ vigilin; $(\mathrm{e}, \mathrm{f})$ glial fibrillary acidic protein (GFAP); $(g, h)$ pan-cytokeratin; and $(i, j)$ stage-specific embryonic antigen 1 (SSEA-1). Mammalian cells were from (b) goat submandibular salivary gland, $(\mathrm{d}, \mathrm{h})$ human parotid salivary gland, (f) Schwann cells isolated from rat nervus ischiadicus, and (j) oocyte-like cells from rat (Danner et al. (2007). Nuclei are stained with DAPI (blue). Scale bars $=100 \mu \mathrm{m}$

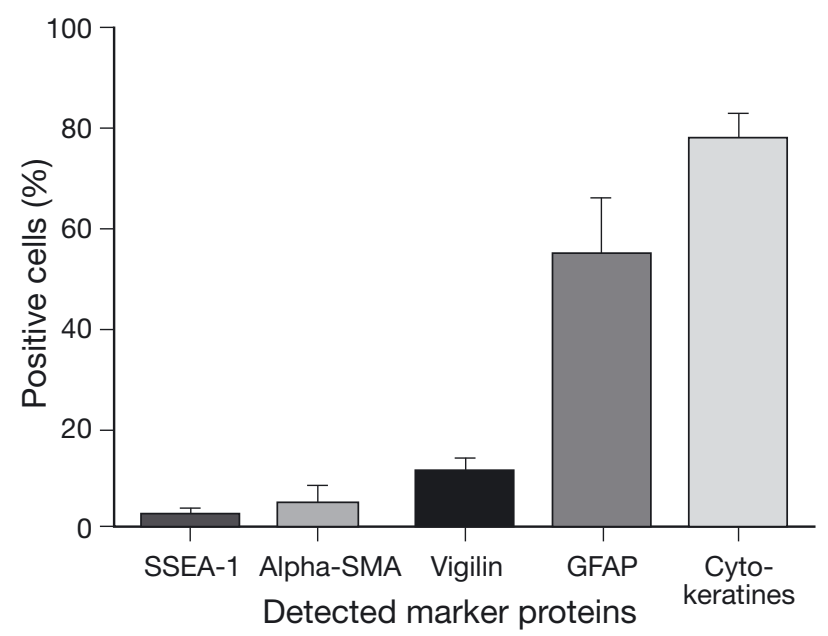

Fig. 4. Clupea harengus. Percentage of cells in herring cell cultures expressing specific proteins as detected immunocytochemically. Cytokeratins and glial fibrillary acidic protein (GFAP) were expressed in many cells, while only a few cells $(<20 \%)$ expressed vigilin, alpha smooth-muscle actin (alphaSMA), and stage-specific embryonic antigen 1 (SSEA-1). Values are mean \pm SD of 3 independent stainings

these proteins were abundantly expressed in our cell population (each was detected in $\sim 50 \%$ of the cells). While vigilin $(\sim 10 \%)$, alpha-SMA, and SSEA-1 (both $\leq 5 \%$ ) were found to be present in subpopulations, the herring protein homologs to nestin, MF20, Oct-4, and Ki-67 could not be detected using anti-human/murine/ rat antibodies. This might be either due to insufficient epitope homology of the actual target proteins and the herring proteins, but it could also indicate that the respective proteins were not expressed by the cells at all.

Summarizing the protein-expression results, it is apparent that indeed, the cell population studied here was diverse and contained several different cell types. The occurrence of cytokeratin-, alpha-SMA-, and SSEA-1-positive cells can be taken as a corroboration of the hypothesis that the cell population contains adult stem cells. Since terminally differentiated cells (such as alpha-SMA-containing smooth-muscle cells) are known to be not proliferative, their presence in the cell culture after many passages indicates that they were produced by the cultured cells.

Proliferation assays revealed that the Atlantic herring cells proliferated significantly faster at $20^{\circ} \mathrm{C}$ than at $16^{\circ} \mathrm{C}$. This might be attributed to metabolism, which becomes slower at lower temperatures. Ganassin et al. (1999) demonstrated that the best growing temperature for Pacific herring larvae cells is between 18 and $21^{\circ} \mathrm{C}$. This is comparable with our data. It should be noted, however, that the optimal temperature for good proliferation needs to be established for every fish species anew. Cells from subtropical fishes like Oryzias latipes are best cultured at $33^{\circ} \mathrm{C}$ (Hirayama et al. 2006), 
while the best proliferation temperature for cells of pelagic fishes like haddock Melanogrammus aeglefinus is reported to be between 12 and $18^{\circ} \mathrm{C}$ (Bryson et al. 2006).

In conclusion, a new long-term proliferative cell population from the adipopancreatic tissue of Clupea harengus has been established. The proliferative activity described here leads us to the assumption that the cell population contains progenitor or adult stem cells. This hypothesis is supported by the results of immunocytochemical analyses. Another important property of this cell population is its excellent suitability for cryopreservation. The proliferative cells may be used in bioreactors for future mass production of valuable proteins, e.g. for nutrition purposes in aquaculture. There was only 1 available herring cell line prior to the present study; now, long-term culturing can prove to be a useful tool for aquaculture industries, toxicological tests, and genetic analysis of herring populations.

Acknowledgements. We thank A. Richter and R. Petschnik. This work was supported by grants of the European Union (EU) and the Business Development and Technology Transfer Corporation of Schleswig-Holstein (WTSH).

\section{LITERATURE CITED}

Babich H, Borenfreund E (1991) Cytotoxicity and genotoxicity assays with cultured fish cells: a review. Toxicol In Vitro 5: 91-100

Bejar J, Borrego JJ, Alvarez MC (1997) A continuous cell line from the cultured marine fish gilt-head seabream (Sparus aurata L.). Aquaculture 150:143-153

Bols NC (1991) Biotechnology and aquaculture: the role of cell cultures. Biotechnol Adv 9:31-49

Bryson SP, Joyce EM, Martell DJ, Lee LE and others (2006) A cell line (HEW) from embryos of haddock (Melanogrammus aeglefinius) and its capacity to tolerate environmental extremes. Mar Biotechnol 8:641-653

Buddington RK, Diamond JM (1987) Pyloric ceca of fish: a 'new' absorptive organ. Am J Physiol 252:G65-G76

> Ciba P, Schicktanz S, Anders E, Siegl E, Stielow A, Klink E, Kruse C (2008) Long-term culture of a cell population from Siberian sturgeon (Acipenser baerii) head kidney. Fish Physiol Biochem 34:367-372

Ciba P, Hering-Hagenbeck S, Nagel U, Kruse C (2010) Examination and recording of stem cells from wild animals; here: snow leopard (Unica unica) and giraffe (Giraffa camelopardialis rothschildi). Zool Gart 79:132-139

Cole AM, Weis P, Diamond G (1997) Isolation and characterization of pleurocidin, an antimicrobial peptide in the skin secretions of winter flounder. J Biol Chem 272: 12008-12013

Danner S, Kajahn J, Geismann C, Klink E, Kruse C (2007) Derivation of oocyte-like cells from a clonal pancreatic stem cell line. Mol Hum Reprod 13:11-20

> Dannevig BH, Falk K, Namork E (1995) Isolation of the causal virus of infectious salmon anaemia (ISA) in a long-term cell line from Atlantic salmon head kidney. J Gen Virol 76:1353-1359

Domeneghini C, Arrighi S, Radaelli G, Bosi G, Mascarello F
(1999) Morphological and histochemical peculiarities of the gut in the white sturgeon, Acipenser transmontanus. Eur J Histochem 43:135-145

Fan T, Ren B, Geng X, Yu Q, Wang L (2010) Establishment of a turbot fin cell line and its susceptibility to turbot reddish body iridovirus. Cytotechnology 62:217-223

Galina J, Yin G, Ardo L, Jeney Z (2009) The use of immunostimulating herbs in fish. An overview of research. Fish Physiol Biochem 35:669-676

Ganassin RC, Sanders SM, Kennedy CJ, Joyce EM, Bols NC (1999) Development and characterization of a cell line from Pacific herring, Clupea harengus pallasi, sensitive to both naphthalene cytotoxicity and infection by viral hemorrhagic septicemia virus. Cell Biol Toxicol 15:299-309

Gorjup E, Danner S, Rotter N, Habermann J and others (2009) Glandular tissue from human pancreas and salivary gland yields similar stem cell populations. Eur J Cell Biol 88: 409-421

Gravell M, Malsberger RG (1965) A permanent cell line from the fathead minnow (Pimephales promelas). Ann NY Acad Sci 126:555-565

Hightower LE, Renfro JL (1988) Recent applications of fish cell culture to biomedical research. J Exp Zool 248:290-302

Hirayama M, Mitani H, Watabe S (2006) Temperature-dependent growth rates and gene expression patterns of various medaka Oryzias latipes cell lines derived from different populations. J Comp Physiol B 176:311-320

Holt SE, Aisner DL, Shay JW, Wright WE (1997) Lack of cell cycle regulation of telomerase activity in human cells. Proc Natl Acad Sci USA 94:10687-10692

Kruse C, Grunweller A, Notbohm H, Kügler S, Purschke WG, Müller PK (1996) Evidence for a novel cytoplasmic tRNAprotein complex containing the $\mathrm{KH}$-multidomain protein vigilin. Biochem J 320:247-252

Kruse C, Birth M, Rohwedel J, Assmuth K, Goepel A, Wedel T (2004) Pluripotency of adult stem cells derived from human and rat pancreas. Appl Phys A 79:1617-1624

Kruse C, Kajahn J, Petschnik AE, Maass A, Klink E, Rapoport DH, Wedel T (2006) Adult pancreatic stem/progenitor cells spontaneously differentiate in vitro into multiple cell lineages and form teratoma-like structures. Ann Anat 188: 503-517

Lakra WS, Swaminathan TR, Joy KP (in press) Development, characterization, conservation and storage of fish cell lines: a review. Fish Physiol Biochem doi:10.1007/s10695010-9411-x

> Lee LE, Dayeh VR, Schirmer K, Bols NC (2009) Applications and potential uses of fish gill cell lines: examples with RTgill-W1. In Vitro Cell Dev Biol Anim 45:127-134

> Lermen D, Blomeke B, Browne R, Clarke A and others (2009) Cryobanking of viable biomaterials: implementation of new strategies for conservation purposes. Mol Ecol 18: 1030-1033

Li F, An H, Seymour TA, Bradford CS and others (1998) Molecular cloning, sequence analysis and expression distribution of rainbow trout (Oncorhynchus mykiss) cystatin C. Comp Biochem Physiol B 121:135-143

Marchetti L, Capacchietti M, Sabbieti MG, Accili D, Materazzi G, Menghi G (2006) Histology and carbohydrate histochemistry of the alimentary canal in the rainbow trout Oncorhynchus mykiss. J Fish Biol 68:1808-1821

- Naylor RL, Goldburg RJ, Primavera JH, Kautsky N and others (2000) Effect of aquaculture on world fish supplies. Nature 405:1017-1024

Ohtani N, Mann DJ, Hara E (2009) Cellular senescence: its role in tumor suppression and aging. Cancer Sci 100: 792-797 
Pilz J, Plantikow H (1991) Sterile isolation and long-term culture of exocrine cells from the pancreas of pike (Esox lucius L.): influence of culture media and the hormone CCK/Pz. In: Braunbeck T, Hanke W, Segner H (eds) Fish: ecotoxicology and ecophysiology; proceedings of an international symposium. VCH, Weinheim, p 337-354

Pittenger MF, Mackay AM, Beck SC, Jaiswal RK and others (1999) Multilineage potential of adult human mesenchymal stem cells. Science 284:143-147

Poulsom R, Alison MR, Forbes SJ, Wright NA (2002) Adult stem cell plasticity. J Pathol 197:441-456

Rapoport DH, Danner S, Kruse C (2009) Glandular stem cells are a promising source for much more than beta-cell replacement. Ann Anat 191:62-69

Reichenbach-Klinke HH (1970) The economic importance of fish diseases. Berl Munch Tierarztl Wochenschr 83: 491-493

Reifel CW, Travill AA (1978) Structure and carbohydrate histochemistry of the stomach in eight species of teleosts. J Morphol 158:155-167

Roche Applied Science (2008) RTCA MP instrument operator's manual. Roche Diagnostics, Mannheim

Sanden M, Berntssen MH, Krogdahl A, Hemre GI, BakkeMcKellep AM (2005) An examination of the intestinal tract of Atlantic salmon, Salmo salar L., parr fed different varieties of soy and maize. J Fish Dis 28:317-330

Schirmer K, Chan AG, Greenberg BM, Dixon DG, Bols NC (1997) Methodology for demonstrating and measuring the photocytotoxicity of fluoranthene to fish cells in culture. Toxicol In Vitro 11:107-119

Seaberg RM, Smukler SR, Kieffer TJ, Enikolopov G and others (2004) Clonal identification of multipotent precursors from adult mouse pancreas that generate neural and

Editorial responsibility: Helmut Segner,

Bern, Switzerland pancreatic lineages. Nat Biotechnol 22:1115-1124

Seeberger KL, Dufour JM, Shapiro AM, Lakey JR, Rajotte RV, Korbutt GS (2006) Expansion of mesenchymal stem cells from human pancreatic ductal epithelium. Lab Invest 86: 141-153

Segner H (1998) Fish cell lines as a tool in aquatic toxicology. EXS 86:1-38

Servili A, Bufalino MR, Nishikawa R, Sanchez de Melo I, Munoz-Cueto JA, Lee LE (2009) Establishment of long term cultures of neural stem cells from adult sea bass, Dicentrarchus labrax. Comp Biochem Physiol A 152:245-254

Tang DG, Tokumoto YM, Apperly JA, Lloyd AC, Raff MC (2001) Lack of replicative senescence in cultured rat oligodendrocyte precursor cells. Science 291:868-871

Tocher DR, Dick JR (1990) Polyunsaturated fatty acid metabolism in cultured fish cells: incorporation and metabolism of $(\mathrm{n}-3)$ and (n-6) series acids by Atlantic salmon (Salmo salar) cells. Fish Physiol Biochem 8:311-319

- Villena AJ (2003) Applications and needs of fish and shellfish cell culture for disease control in aquaculture. Rev Fish Biol Fish 13:111-140

- Wise JP Sr, Wise SS, Goodale BC, Shaffiey F, Kraus S, Walter RB (2009) Medaka (Oryzias latipes) as a sentinel species for aquatic animals: medaka cells exhibit a similar genotoxic response as North Atlantic right whale cells. Comp Biochem Physiol C 149:210-214

> Wolf K, Vestergard Jorgensen PE (1970) Salmonid viruses: double infection of RTG-2 cells with Egtved and infectious pancreatic necrosis viruses. Arch Ges Virusforsch 29: $337-342$

Zhao Z, Lu Y (2006) Establishment and characterization of two cell lines from bluefin trevally Caranx melampygus. Dis Aquat Org 68:91-100

Submitted: July 21, 2010; Accepted: December 27, 2010

Proofs received from author(s): February 3, 2011 